\title{
Quality Assessment of Honey in Three Different Geographical Areas from Republic of Moldova
}

\author{
Aurica Chirsanova, Tatiana Capcanari, Alina Boistean \\ Department of Food and Nutrition, Technical University of Moldova, Chisinau, Republic of Moldova \\ Email: aurica.chirsanova@toap.utm.md
}

How to cite this paper: Chirsanova, A., Capcanari, T. and Boistean, A. (2021) Quality Assessment of Honey in Three Different Geographical Areas from Republic of Moldova. Food and Nutrition Sciences, 12, 962977.

https://doi.org/10.4236/fns.2021.1210071

Received: September 17, 2021

Accepted: October 24, 2021

Published: October 27, 2021

Copyright ( 2021 by author(s) and Scientific Research Publishing Inc. This work is licensed under the Creative Commons Attribution International License (CC BY 4.0).

http://creativecommons.org/licenses/by/4.0/

\begin{abstract}
One of the empirical and image products of the Republic of Moldova is bee honey. Its assortment is due to the variety of landforms, as well as the diversity of flora specific to geographical regions. During the Covid-19 pandemic, domestic consumers had limited access to bee honey. This was caused by the restrictions imposed in order to organize fairs and agricultural markets which are one of the main sources for the purchase of bee products in the Republic of Moldova. At the same time, the analysis of trademarks in supermarkets highlighted the preferences of honey consumption as follows: polyfloral honey $-28.57 \%$, lime honey-20.40\% and acacia honey-14.28\%. In order to evaluate the quality of honey from small producers and highlight the specific characteristics of geographical areas, 60 samples were analyzed that included 3 types of honey: polyflora, sunflower and linden collected from 3 different geographic areas: Soroca area (North), area Ungheni (Center), Stefan Voda area (South). Honey samples were declared harvest of 2020. They were analyzed physico-chemically using methods provided by national and EU standards. The results obtained from the analysis of pollen in honey confirm the botanical origin declared by beekeepers and allowed to highlight the types of pollen specific to each area. Following the determination of qualitative indices: reaction with ethyl alcohol, with resorcinol; insoluble matter, cereal flour, gelatin and starch, it was found that the most inconsistencies were found in linden honey. Some indicators were close to the maximum permissible values specified in regulatory documents. The water content found in the honey samples was quite varied, and ranged from $16.05 \% \pm 0.11 \%$ to $19.89 \% \pm$ $0.13 \%$, but these samples were within the limits of the standards. Total acidity ranged from $6.19 \pm 0.13$ to $27.20 \pm 0.03$ which falls within the established norms (up to $50.00 \mathrm{~cm}^{3} \mathrm{NaOH}$ solution in (milliequivalents) per $100 \mathrm{~g}$ of honey). According to the SIE Lab space, all samples have a yellowish tint, this is indicated by positive values on the $b^{*}$ axis. However, honey samples from the southern region of Moldova showed the presence of greenish pollen, as evi-
\end{abstract}


denced by the reduced values on the $\mathrm{a}^{\star}$ axis. Our research reveals the quality level of honey from three different areas of the Republic of Moldova and the variation of quality parameters due to factors such as geographical region, climatic conditions, botanical origin and handling or storage conditions.

\section{Keywords}

Honey, Physico-Chemical Indices, Geographical Areas, Republic of Moldova, Covid-19 Impact

\section{Introduction}

According to the latest report from the European Commission on the beekeeping market, the European Union is the world's second largest producer of honey after China, with an average production of 230.000 tons per year and a total of 17.5 million hives, owned by 650.000 beekeepers. The self-sufficiency rate in the European Union is $60 \%$, the rest of the demand being covered by imported honey. The Republic of Moldova has, in turn, a rich tradition regarding honey production, with an average of 4.000 tons per year, which is mostly exported to the European Union [1].

Regarding the consumption of bee products, it differs depending on the tradition of each country [2], but also depending on sociodemographic factors such as gender, age, family structure, education, income, occupation and residence [3]. Honey is an emblematic product of the Republic of Moldova [4] - this positioning determines the particular interest of the beekeeping sector [5]. The export of honey in 2019 in tonnes is shown in Figure 1, in 2020 there was an increase in the export of honey by $14 \%$ [6].

It should be mentioned that a maximum of $15 \%$ of the total volume of honey produced in the Republic of Moldova is consumed locally. The price of honey sold to individuals is twice as high as the wholesale price offered by large intermediaries. However, low wholesale prices, as well as high production costs, stop investment in the honey sector. At present, about $85 \%$ of the production volume is exported. For our country, the main market is the European Union, which assimilates over $90 \%$ of exported honey, while in 2015 , the ratio was $98 \%$. The main honey destinations in the Republic of Moldova are Italy, Germany, France, Slovakia, but also smaller, but still considerable markets, such as Romania, Poland, Denmark, etc. [8].

Its sustainable development contributes not only to socio-economic development, but also to rural development and the maintenance of biodiversity. From an economic point of view, beekeeping is an income-generating and marketcreating activity with a high rate of return on investment [9].

In the context of the mentioned above, the study of the beekeeping sector can contribute to the tracking process of the path of products from producer to consumer and to the development of strategies for all the involved actors. Existing 


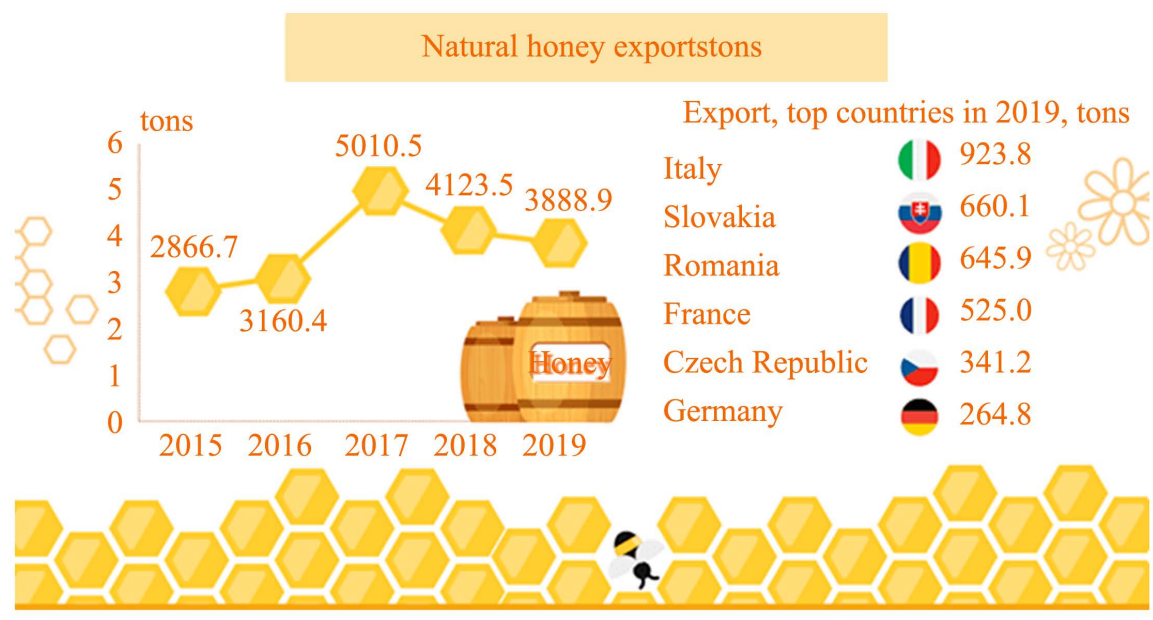

Figure 1. Honey export from the republic of Moldova [7].

scientific research draws attention to several problems in the beekeeping sector, namely counterfeiting of honey and fraud [10] of the botanical and geographical origin of the product. According to a report of the EU Food Fraud Network, honey is listed third in the ranking of potentially counterfeit products in the European Union [11]. Additionally, the consumers are not sufficiently informed about the quality and integrity of the honey they consume [12].

The geographical position of the territory of Moldova gives its climate a pronounced continental character, with frequent occurrences of drought. Climatic peculiarities lead to the presence of three agro-climatic regions: north, central and south. The following is typical for the northern region: the sum of the average daily active temperatures in $2.700^{\circ} \mathrm{C}-3.000^{\circ} \mathrm{C}$ is limiting; the maximum rainfall is $451-711 \mathrm{~mm} /$ year; temperature above $10^{\circ} \mathrm{C}$ is equivalent to $167-176$ days/year. For the central agro-climatic region, compared to the northern region, the following is typical: higher level of average daily active temperatures $\left(100^{\circ} \mathrm{C}-200^{\circ} \mathrm{C}\right.$ higher $)$; longer period with temperatures higher than $10^{\circ} \mathrm{C}(6$ 10 days more) and less precipitation (14-93 mm less). The southern region is warmer and less humid than the northern area. The sum of the average daily active temperatures here is up to $3.300^{\circ} \mathrm{C}$ and the duration of the period with the temperature higher than $10^{\circ} \mathrm{C}$ is longer, 11 - 12 days, and the amount of precipitation is lower than in the northern area $(70-120 \mathrm{~mm}$ /year; Hydrometeorological Center 1982) [13].

Given that the Republic of Moldova is an agrarian country and bee honey is one of the country's image products, keeping quality under control and adjusting to European standards becomes a very important issue [14].

It is important to note that honey from the Republic of Moldova is produced by both industrial beekeepers and small-scale artisanal beekeepers, who work closely with consolidators, processors and exporters. The honey obtained is genuine, subject to strict quality controls throughout the production cycle, to ensure purity in every drop. In order to meet the growing demand of consumers of 
organic products, Moldovan producers, consolidators and processors tend to turn their production, increasingly, into organic production. At the same time, the Republic of Moldova meets the standards of the European Union for the quality of honey, in accordance with Directive 110/2001 of the European Council. The country is a "certified third party" by the EU for compliance with drug and pesticide residue analysis. All disease and parasite control products that are used in Moldova are EU approved. Moldovan honey exporters offer buyers a range of packaging options, from single-serving packages to $300 \mathrm{~kg}$ barrels. Packaging options also include jars weighing between $30 \mathrm{~g}$ and $950 \mathrm{~g}$, as well as single-dose packs of 8 - $20 \mathrm{~g}$ [15] [16].

At the same time, the National Beekeeping Development Program in the Republic of Moldova for 2020-2026 clearly mentions the general objective, namely: increase the number of bees, increase the productivity of hives and develop the range of bee products by applying modern technologies and promoting the practice of professional beekeeping in order to increase the production and export volume up to 8.2 thousand tons in 2026 [8]. The specific objectives regarding the development of the beekeeping sector and the achievement of the general objective are presented in Figure 2.

Based on the specific objectives mentioned above, the vector of beekeeping research must be firmly oriented towards the physico-chemical indices and the authenticity of honey because these indicators are essential for the certification

Increasing the beekeeping heritage and increasing the productivity of apiaries, following that in the next 7 years the number of bee families will be doubled,up to 300 thousand families;

Improving the local beekeeping genetic fund and the health status of bee families, providing $50 \%$ of the annual demand for local bee genetic material by 2026 ;

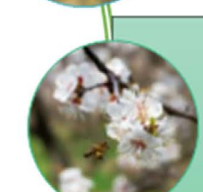

Diversification of bee production and strengthening the processing and production capacities of value-added bee products through cooperation and clustering, reaching that by 2026 about $80 \%$ of the annual volume of global bee production will be value-added bee products (monofloral honey,wax, pollen, royal jelly, propolis, the rapeutic products, etc.);

Promoting the culture of honey consumption and stimulating local trade and export of honey, tripling the consumption of honey per capita and maintaining the rate of $90 \%$ of export production until 2026;

Stimulating the practice of industrial beekeeping by strengthening the capacity of beekeepers and increasing the number of young specialists in the sector, reaching at least $15 \%$ of beekeepers to have at least 150 families and to double the number of specialists trained annually in the sector by 2026 .

Figure 2. Specific objectives regarding the development of the beekeeping sector in the Republic of Moldova. 
process and determine the quality of honey. This, in turn, represents the success of bee products on both the local and foreign markets [17].

In this study, three different types of bee honey collected from three geographical regions of the Republic of Moldova were analyzed, namely from the northern, central and southern areas. The objectives of this study were: to highlight the types of bee honey in major Moldovan supermarkets available to consumers during the Covid-19 pandemic; to analyze and compare physico-chemical indices from bee honey of different botanical origin collected in different regions of the Republic of Moldova, to determine and compare the content of polyphenols, flavonoids and DPPH between bee honey of the same botanical origin taken from different geographical regions of the Republic Moldova; to compare the data obtained with the data in the literature.

\section{Materials and Methods}

The research was conducted between November 2020-March 2021. The assortment of honey on the shelves of the largest supermarket chains in the Republic of Moldova (in the capital Chisinau) was examined (Nr1, Kaufland, Metro cash \& carry, Linella, Bonus, Fourchette), which were available to consumers during the pandemic. Determination of physico-chemical parameters was performed in the laboratories of the Department of Food and Nutrition of the Faculty of Food Technology of the Technical University of Moldova. During the research, the honey samples were kept in laboratory conditions, packed in glass jars, hermetically sealed, at a temperature of $20^{\circ} \mathrm{C} \pm 2^{\circ} \mathrm{C}$.

\section{Honey samples}

The study included nine honey samples from three different apiaries from the Republic of Moldova, which include three types of the most specific honeycombs, namely polyfloral honey, sunflower honey and linden honey. Samples of honey were collected in 2020 and come from different geographical regions of the Republic of Moldova: Soroca, Ungheni and Stefan Voda. The characteristics of the geographical origin and abbreviations of the samples are presented in the Table 1 .

In order to highlight the physico-chemical indices have been determined: Mass fraction of water, Inverted sugar, Sucrose, pH, Total acidity, Ash content, Water insoluble matter, presence of cereal flour, presence of starch. All results were evaluated on the basis of Codex Alimentarius Commission (CAC, 2001) [18] and harmonized methods of the International Honey Commission (Table 2).

Palynological analysis It was performed by microscopic analysis according to the method of Chuttong and al. (2018) [19].

Mass fraction of water was determined using Honey humidity refractometer ATAGO 4422 PAL-22S, $12.0 \%$ to $30.0 \%$, acc. $\pm 0.2 \%$.

The $\mathrm{pH}$ of the samples was measured potentiometrically at $20^{\circ} \mathrm{C}$ using a $\mathrm{pH}$ meter (HANNA 2211 - 02) bench meter with an electrode holder. Aqueous solutions 
Table 1. Characteristics of the geographic origin of the examined honey samples.

\begin{tabular}{|c|c|c|c|c|}
\hline Nr. & $\begin{array}{c}\text { Geographical } \\
\text { area }\end{array}$ & Geographical position & Honey samples & \\
\hline & & & $\begin{array}{l}\text { Polyfloral honey } \\
\qquad(\mathrm{n}=7)\end{array}$ & \\
\hline 1 & $\begin{array}{l}\text { North of } \\
\text { Moldova, } \\
\text { Soroca area }\end{array}$ & $\begin{array}{c}48^{\circ} 09^{\prime} 21^{\prime \prime N} 28^{\circ} 17^{\prime} 51^{\prime \prime} \mathrm{E} \\
\text { The altitude is about } \\
45 \mathrm{~m} \text { above sea level }\end{array}$ & $\begin{array}{l}\text { Sunflower honey } \\
\qquad(\mathrm{n}=5)\end{array}$ & \\
\hline & & & $\begin{array}{l}\text { Linden honey } \\
\quad(\mathrm{n}=5)\end{array}$ & \\
\hline & & & $\begin{array}{l}\text { Polyfloral honey } \\
\qquad(\mathrm{n}=11)\end{array}$ & \\
\hline 2 & $\begin{array}{l}\text { Center of } \\
\text { Moldova, } \\
\text { Ungheni area }\end{array}$ & $\begin{array}{c}47^{\circ} 11^{\prime} 15^{\prime \prime} \mathrm{N} 27^{\circ} 47^{\prime} 45^{\prime \prime} \mathrm{E} \\
\text { The altitude is about } \\
62 \mathrm{~m} \text { above sea level }\end{array}$ & $\begin{array}{l}\text { Sunflower honey } \\
\qquad(\mathrm{n}=8)\end{array}$ & $\begin{array}{l}\text { 1) Soroca area } \\
\text { 2) Ungheni area } \\
\text { 3) Ștefan Vodă area }\end{array}$ \\
\hline & & & $\begin{array}{l}\text { Linden honey } \\
\quad(\mathrm{n}=7)\end{array}$ & \\
\hline 3 & $\begin{array}{l}\text { South of } \\
\text { Moldova, } \\
\text { Ștefan } \\
\text { Vodă area }\end{array}$ & $\begin{array}{c}46^{\circ} 30^{\prime} 55^{\prime \prime} \mathrm{N} 29^{\circ} 39^{\prime} 47^{\prime \prime} \mathrm{E} \\
\text { The altitude is about } \\
141 \mathrm{~m} \text { above sea level }\end{array}$ & $\begin{array}{l}\text { Polyfloral honey } \\
\qquad(\mathrm{n}=7) \\
\text { Sunflower honey } \\
\quad(\mathrm{n}=5) \\
\text { Linden honey } \\
(\mathrm{n}=5)\end{array}$ & \\
\hline
\end{tabular}

Table 2. Physico-chemical indices and the considered references.

\begin{tabular}{ccc}
\hline Nr. & Physico-chemical indices & Specifications \\
\hline 1 & Mass fraction of water & max. 20.0 \\
2 & Inverted sugar & min. 65.0 \\
3 & Sucrose & max. 8.0 \\
4 & $\mathrm{pH}$ & $3.24-6.1$ \\
$\mathbf{5}$ & Total acidity & max. 4.0 \\
6 & Ash & max. 0.5 \\
7 & Water insoluble matter & absent \\
8 & Presence of cereal flour & absent \\
9 & Presence of starch & absent \\
\hline
\end{tabular}

of honey were prepared by dissolving $1 \mathrm{~g}$ of honey in $10 \mathrm{~mL}$ distilled water $(10 \%$ $\mathrm{w} / \mathrm{v})$.

Total acidity is determined by the potentiometric method. The water content is determined by measuring the refractive index at $20^{\circ} \mathrm{C}$ at using an abbe-type refractometer.

To determine the invert sugar (by the Elser method) it was taken into account that glucose and fructose, in the free state, have the ability to reduce copper sulfate in an alkaline and hot environment, which it transforms into copper oxide.

The amount of copper oxide that is formed under specific working conditions 
is proportional to the concentration of the two reducing sugars in the solution to be researched.

Total ash content was determined according to the method of incineration of honey samples. The ash content is a quality criterion for honey origin, the blossom honeys having a lower ash content than the honeydew ones.

For the determination of sucrose (by Elser method) the direct reducing sugar was determined before and after inversion (acid hydrolysis), and from the difference sucrose is calculated.

\section{Determination color parameters}

The chromaticity coordinates [ $\mathrm{L}^{\star}$-lightness, $a^{\star}$ (positive values)-redness/greenness (negative values), $b^{*}$ (positive values)-yellowness/blueness (negative values)] of honey samples were measured using an optical sensor colorimeter (Chroma Meter CR-400 Head) in an equal volume of native honey. Prior measurements, the instrument was calibrated with a black and white standard plate.

$C$-chroma describes the vividness or dullness of a colour-in other words, how close the colour is to either grey or the pure hue. Chroma values were determined using the formula on the basis of $a^{*}$ and $b^{*}$ color parameters:

$$
C^{*}=\sqrt{a^{* 2}+b^{* 2}}
$$

$H^{\circ}$-hue is how we perceive an object's colour-red, orange, green, blue, etc. The same holds for hue, angle which was determined using the formula:

$$
H^{\circ}=\arctan \left(b^{*} / a^{*}\right) ;
$$

Chroma and hue angle values were determined according to K. Karabagias et al. (2018) [20].

The color of honey was also determined through spectrophotometric measurement of $50 \%$ honey solution $(\mathrm{m} / \mathrm{v})$ with absorbance reading at $635 \mathrm{~nm}$. The results of absorbance were correlated with the Pfund scale (Table 3) according to Scholz et al. (2020) [21].

Statistical Analyses. All laboratory methods were run in 3 replicates and the results were expressed as means with standard deviations (SD). The significant differences represented by letters were obtained by a one-way analysis of variance (ANOVA) followed by Tukey's honestly significant difference (HSD) post

Table 3. Color category to the Pfund scale.

\begin{tabular}{cc}
\hline Color & Pfund (mm) \\
\hline Water white & $\leq 8$ \\
Extra white & $8 \leq 17$ \\
White & $17 \leq 34$ \\
Extra light amber & $34 \leq 50$ \\
Light amber & $50 \leq 85$ \\
Amber & $85 \leq 114$ \\
Dark amber & $>114$ \\
\hline
\end{tabular}


hoc test $(\mathrm{P}<0.05)$. Static data processing was performed using the ANOVA program, mean and standard deviation were calculated using Microsoft Excel 2019.

\section{Results and Discussions}

\subsection{Honey Brands in the Major Supermarkets of Moldova}

To get a better understanding of what the choice of honey was consumer during a pandemic, assortment studies were conducted on supermarket chains authorized to sell during a severe pandemic.

The quantitative ratio of varieties of honey sold in the largest supermarkets in Chisinau is shown in the Figure 3. During the research period polyfloral honey occupied the largest share in the assortment-28.57\%. Linden honey ranks second in the ranking-20.40\%. Also, a significant share in the total assortment is occupied by acacia honey- $14.28 \%$.

The quantitative ratio of varieties of honey is due to the preferences of local consumers.

The examination of the label revealed the presence of such information as: labeling, name and type of product, year of collection, name and location of the manufacturer, weight, energy value per $100 \mathrm{~g}$, storage period and conditions, date of packing. It was established that not all labels indicated the documents according to which the product was manufactured.

The volume of the product varied from $12 \mathrm{~g}$ to $1 \mathrm{~kg}$, and the honey was packed in polyethylene bags for single use or in glass jars. In all the surveyed supermarkets, only 6 producers were identified, while in Moldova more than 7.8 thousand beekeepers are registered.

It should be noted that there have been no studies of consumer preferences of various types of honey in the Republic of Moldova. Research conducted in Romania (neighboring country with close geo-climatic and social conditions) shows that the most preferred honey is polyfloral as in the case of consumers preferences from the Republic of Moldova. On the second position is acacia honey (Popescu et al., 2019) [22]. On the other hand, consumers in Ukraine, the

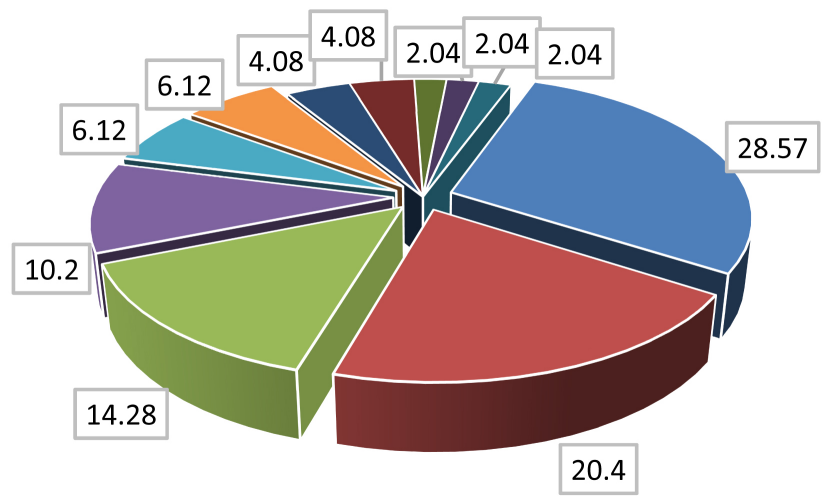

- polyfloral honey

- linden honey

- acacia honey

- sunflower honey

- sage honey

- coriander honey

- buckwheat honey

- lavender honey

- rapeseed honey

- forest honey

- raspberry honey

Figure 3. The quantitative ratio of varieties of honey sold in supermarkets in Chisinau. 
second neighboring country that has a common border with the Republic of Moldova in the west, prefer the consumption of polyfloral honey and sunflower [23].

After analyzing the results obtained, the following problems can be identified that prevent local beekeepers from expanding their marketing boundaries:

$\checkmark$ According to the data, the production of honey in the Republic of Moldova has grown by $63 \%$ in five years, and it should be noted that the leading position in the production of honey was taken by the private sector [24] [25]. This fact contributes to increased competition between honey producers.

$\checkmark$ During the pandemic, all state requirements and programs for the quality and improvement of the beekeeping industry were available only in electronic form. But not all small producers have the ability and skill to use them.

$\checkmark$ In addition to the constraints and connectivity issues due to the pandemic, small-scale honey producers are constrained by tariff barriers and local duties.

$\checkmark$ And also, the situation was complicated by the increase in the volume of imports of cheap honey, as a result, for many domestic beekeepers, the problem of selling the produced honey has become urgent.

Considering the above, in the following studies, three types of honey were used that were established as the most consumed in the severe period of the Covid-19 pandemic in the Republic of Moldova, Chisinau.

\subsection{Pollen Analysis}

Determining the floral origin of honey can be done by analyzing the pollen profile that allows us to affirm or refute the information declared by beekeepers. The frequency of pollen grains identified in the analyzed honey is presented in Table 4.

In the floral honey was identified a large number of pollens that was found decreasing in the honey from the three geographical areas of the Republic of Moldova (in the northern area there are 7 types of pollen, center 6 and south 4). In sunflower honey, Heliánthus ánnuus pollen was dominant and the maximum amount was in the northern area $(7.00 \%-74.05 \%)$. In linden honey the content of the dominant pollen varied (from $47.11 \%-47.69 \%$ for the southern area to $80.05 \%-81.90 \%$ in the northern area). The obtained results confirm the botanical origin of the honey declared by the beekeepers and we can assume that the honey was filtered and packaged in accordance with the requirements and norms.

\subsection{Determination of Honey Adulteration}

In order to determine the adulteration of the analyzed honey samples, the following qualitative indices were determined: reaction with ethyl alcohol, with resorcinol; water-insoluble matter, cereal flour, gelatin and starch. The results in Table 5 denote that 3 of out of the 60 analyzed samples presented water-insoluble substance. This was confirmed by the white precipitate and the intense reddish 
Table 4. The pollen analysis results of honey samples from different areas of Moldova.

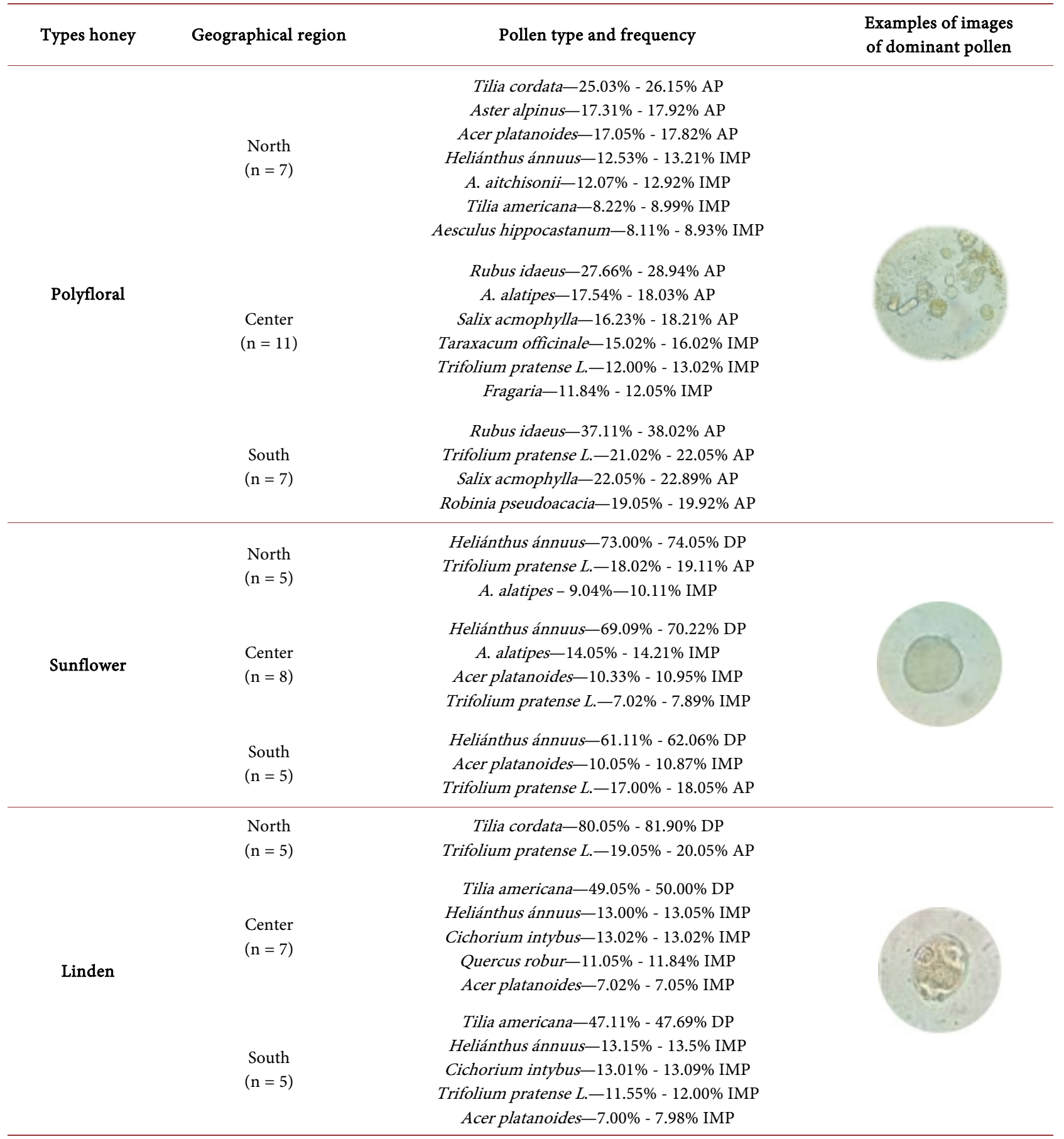

Dominant pollen/DP > 45\%; accompanying pollen/AP 15\% - 45\%; important minor pollen/IMP 3\% - 15\%; minor pollen/MP > 1\% [26].

Table 5. Determines the adulteration of honey samples from the republic of Moldova.

\begin{tabular}{|c|c|c|c|c|c|c|c|}
\hline Types honey & Geographical region & $\begin{array}{l}\text { Reaction with } \\
\text { ethyl alcohol }\end{array}$ & $\begin{array}{l}\text { Reaction with } \\
\text { resorcinol }\end{array}$ & $\begin{array}{l}\text { Water-insoluble } \\
\text { matter, \% }\end{array}$ & $\begin{array}{l}\text { Cereal } \\
\text { flour }\end{array}$ & Gelatin & Starch \\
\hline \multirow{3}{*}{ Polyfloral } & North $(\mathrm{n}=7)$ & Negative & Negative & Negative & Absent & Absent & Absent \\
\hline & Center $(\mathrm{n}=11)$ & Negative & Negative & Negative & Absent & Absent & Absent \\
\hline & South $(\mathrm{n}=7)$ & Negative & Negative & Negative & Absent & Absent & Absent \\
\hline
\end{tabular}


Continued

\begin{tabular}{|c|c|c|c|c|c|c|c|}
\hline & North $(\mathrm{n}=5)$ & Negative & Negative & Negative & Absent & Absent & Absent \\
\hline \multirow[t]{4}{*}{ Sunflower } & Center $(\mathrm{n}=8)$ & Negative & Negative & Negative & Absent & Absent & Absent \\
\hline & South $(\mathrm{n}=5)$ & Negative & Negative & Negative & Absent & Absent & Absent \\
\hline & North $(\mathrm{n}=4)$ & Negative & Negative & Negative & Absent & Absent & Absent \\
\hline & North $(\mathrm{n}=1)$ & White precipitate & Intense Red Colour & 0,09 & Absent & Absent & Present \\
\hline \multirow[t]{3}{*}{ Linden } & Center $(n=5)$ & Negative & Negative & Negative & Absent & Absent & Absent \\
\hline & Center $(\mathrm{n}=2)$ & White precipitate & Intense Red Colour & 0,08 & Absent & Absent & Present \\
\hline & South $(\mathrm{n}=5)$ & Negative & Negative & Negative & Absent & Absent & Absent \\
\hline
\end{tabular}

color that appeared when reacting with ethyl alcohol and resorcinol. The intense red color is obtained in response to the reaction with resorcinol and we can affirm that the honey was subjected to heat treatment or stored in inadequate conditions without respecting the temperature regime [27].

However, water-insoluble substances with a content of $0.09 \%$ and $0.08 \%$, respectively, were also identified in these samples, but the quantity was within the permissible limit (maximum 0.1\%). Other results obtained from the research that captured our attention were the presence of starch in the same 3 samples of linden honey from North and Centre of the Republic of Moldova. The results presented above showed that these honey samples were susceptible to external interference. Probably the water-insoluble substance represents pollen.

\subsection{Physico-Chemical Indices of Honey}

In the last 10 years in the Republic of Moldova has doubled honey production and the authorities announced major plans in this area. In this context, it is necessary to be kept under control the quality of local honey. At the same time, honey from the Republic of Moldova is known as a good quality product that requires continuous monitoring [28] [29].

The water content found in the honey samples was quite varied, and ranged from $16.05 \% \pm 0.11 \%$ for sunflower honey from the south to $19.89 \% \pm 0.13 \%$ for linden honey from the northern area (Table 6). These samples were within the limits of the standards ( 20\%) according to the International Quality Regulations [18].

It is known that a higher water content could cause unwanted fermentation of honey during storage and formation of acetic acid [30]. At the same time, the water content in honey depends on various factors, including the harvest season, the degree of maturity reached in the hive, geographical and environmental factors [31] [32].

Total acidity, $\mathrm{pH}$ and ash content were determined for the purpose of highlighting and comparison with International Requirements. Thus, we observe that the total acidity ranged from $6.19 \pm 0.13$ for linden honey from North part of Republic of Moldova to $27.20 \pm 0.03$ for polyfloral honey from south part which falls within the established norms (up to $50.00 \mathrm{~cm}^{3} \mathrm{NaOH}$ solution in (milliequivalents) per $100 \mathrm{~g}$ of honey). 
Table 6. Physico-chemical indices of honey samples from the republic of Moldova.

\begin{tabular}{cccccccc}
\hline \multirow{2}{*}{ Types honey } & $\begin{array}{c}\text { Geographical } \\
\text { region }\end{array}$ & $\begin{array}{c}\text { Water content, } \\
\%\end{array}$ & $\begin{array}{c}\text { Total acidity, } \\
\mathrm{cm}^{3}\end{array}$ & $\mathrm{pH}$ & $\begin{array}{c}\text { Ash, } \\
\%\end{array}$ & $\begin{array}{c}\text { Inverted sugar, } \\
\%\end{array}$ & $\begin{array}{c}\text { Sucrose, } \\
\%\end{array}$ \\
\hline \multirow{3}{*}{ Polyfloral } & North $(\mathrm{n}=7)$ & $18.02 \pm 0.11^{\mathrm{g}}$ & $27.03 \pm 0.02^{\mathrm{a}}$ & $4.08 \pm 0.10^{\mathrm{e}}$ & $0.39 \pm 0.03^{\mathrm{i}}$ & $81.02 \pm 0.11^{\mathrm{b}}$ & $0.65 \pm 0.02^{\mathrm{g}}$ \\
& Center $(\mathrm{n}=11)$ & $17.99 \pm 0.07^{\mathrm{a}}$ & $26.60 \pm 0.11^{\mathrm{a}}$ & $4.05 \pm 0.11^{\mathrm{d}}$ & $0.41 \pm 0.04^{\mathrm{a}}$ & $80.17 \pm 0.13^{\mathrm{f}}$ & $0.71 \pm 0.11^{\mathrm{g}}$ \\
& South $(\mathrm{n}=7)$ & $17.02 \pm 0.19^{\mathrm{c}}$ & $27.20 \pm 0.03^{\mathrm{g}}$ & $4.06 \pm 0.12^{\mathrm{a}}$ & $0.35 \pm 0.07^{\mathrm{g}}$ & $82.13 \pm 0.04^{\mathrm{a}}$ & $0.98 \pm 0.03^{\mathrm{c}}$ \\
\hline \multirow{2}{*}{ Sunflower } & North $(\mathrm{n}=5)$ & $17.52 \pm 0.17^{\mathrm{g}}$ & $26.20 \pm 0.12^{\mathrm{i}}$ & $4.05 \pm 0.06^{\mathrm{c}}$ & $0.38 \pm 0.02^{\mathrm{c}}$ & $83.00 \pm 0.10^{\mathrm{b}}$ & $1.49 \pm 0.07^{\mathrm{g}}$ \\
& Center $(\mathrm{n}=8)$ & $16.86 \pm 0.24^{\mathrm{e}}$ & $24.38 \pm 0.02^{\mathrm{b}}$ & $4.01 \pm 0.03^{\mathrm{g}}$ & $0.49 \pm 0.04^{\mathrm{a}}$ & $81.21 \pm 0.12^{\mathrm{d}}$ & $1.51 \pm 0.11^{\mathrm{a}}$ \\
& South $(\mathrm{n}=5)$ & $16.05 \pm 0.11^{\mathrm{b}}$ & $22.09 \pm 0.01^{\mathrm{b}}$ & $3.68 \pm 0.04^{\mathrm{b}}$ & $0.31 \pm 0.03^{\mathrm{f}}$ & $76.91 \pm 0.14^{\mathrm{g}}$ & $1.69 \pm 0.13^{\mathrm{d}}$ \\
\hline \multirow{3}{*}{ Linden } & North $(\mathrm{n}=5)$ & $19.89 \pm 0.13^{\mathrm{a}}$ & $6.19 \pm 0.13^{\mathrm{d}}$ & $4.14 \pm 0.05^{\mathrm{i}}$ & $0.28 \pm 0.06^{\mathrm{a}}$ & $75.98 \pm 0.11^{\mathrm{c}}$ & $0.84 \pm 0.01^{\mathrm{c}}$ \\
& Center $(\mathrm{n}=7)$ & $18.78 \pm 0.09^{\mathrm{g}}$ & $19.10 \pm 0.02^{\mathrm{i}}$ & $3.24 \pm 0.06^{\mathrm{c}}$ & $0.21 \pm 0.02^{\mathrm{e}}$ & $74.11 \pm 0.02^{\mathrm{b}}$ & $1.12 \pm 0.06^{\mathrm{f}}$ \\
& South $(\mathrm{n}=5)$ & $18.70 \pm 0.89^{\mathrm{b}}$ & $9.98 \pm 0.03^{\mathrm{c}}$ & $3.32 \pm 0.10^{\mathrm{g}}$ & $0.50 \pm 0.11^{\mathrm{i}}$ & $83.91 \pm 0.01^{\mathrm{b}}$ & $1.41 \pm 0.12^{\mathrm{a}}$ \\
\hline
\end{tabular}

Note: a-i: in each column different letters mean significant differences $(\mathrm{P}<0.05)$.

It should be noted that the acidity of honey is a quality parameter that helps to assess the freshness of honey [15]. Thus, based on the acidity values of experimental samples, it was established that the analyzed honey was harvested in 2020 .

The $\mathrm{pH}$ of the honey samples ranged from $3.24 \pm 0.06$ to $4.14 \pm 0.05$ and the average $\mathrm{pH}$ of the examined honey sample was 3.81. The allowed ash con-tent in honey is a maximum of $0.5 \%$. In two researched samples the ash content was at the maximum allowable limit [18].

The content of invert sugar and sucrose in honey are essential indicators of their quality [16] [33]. The average mass fraction of sugar was $80.06 \%(74.11 \%-$ $83.91 \%)$ and the average mass fraction of sucrose was $1.043 \%(0.65 \%-1.69 \%)$. These indices fall within the established norms: the mass fraction of invert sugar of at least $65.0 \%$ and the mass fraction of sucrose of maximum $8.0 \%$.

Simultaneously it was measured colour by the Chroma meter CR 400. The results presented are shown in Table 7.

The color of honey is characteristic of its floral source due to minerals and other minor components. Exposure to heat and storage time may affect honey's color. Honey appears lighter in color after it has granulated [34].

Table 7 depicted a descriptive analysis color influential physicochemical parameter in CIE Lab space. In accordance with these results using the CIE Lab space, the lowest value of L (lightness) corresponds to the dark honey with mean values for samples of sunflower honey (average 32.45). The samples from the South of Moldova have the least low L value, which indicates the presence of the darkest shades of pollen. The highest $\mathrm{L}$ value was noted in polyfloral honey samples (mean 35.4). Samples from the south of Moldova also have the highest $\mathrm{L}$ value, which indicates the presence of the lightest shades of pollen.

The difference between kinds of honey in function of the components $a^{*}$ and $\mathrm{b}^{*}$ are statistical significative $(\mathrm{P}<0.001)$. Greenish (negative $\mathrm{a}^{*}$ values) were recorded in polyfloral honey samples from South of Moldova area $(-0.56)$, and 
Table 7. Color parameters of honey samples from the Republic of Moldova.

\begin{tabular}{|c|c|c|c|c|c|c|c|}
\hline Types honey & Geographical region & $\begin{array}{c}\mathrm{L}^{*} \\
\text { Mean } \pm \mathrm{SD}\end{array}$ & $\begin{array}{c}a^{*} \\
\text { Mean } \pm S D\end{array}$ & $\begin{array}{c}b^{*} \\
\text { Mean } \pm S D\end{array}$ & Chroma* & $\mathrm{Hue}^{\circ}$ & $\begin{array}{c}\text { Color } \\
\text { (mmPfund) }\end{array}$ \\
\hline \multirow{3}{*}{ Polyfloral } & North $(\mathrm{n}=7)$ & $27.99 \pm 0.12^{\mathrm{g}}$ & $3.25 \pm 0.04^{\mathrm{b}}$ & $12.63 \pm 0.01^{\mathrm{g}}$ & $5.64 \pm 0.02^{\mathrm{g}}$ & $1.32 \pm 0.08^{\mathrm{e}}$ & $29 \pm 0.03^{g}$ \\
\hline & Center $(n=11)$ & $33.03 \pm 0.09^{d}$ & $2.27 \pm 0.05^{\mathrm{e}}$ & $18.96 \pm 0.03^{c}$ & $6.52 \pm 0.02^{c}$ & $1.45 \pm 0.05^{\mathrm{c}}$ & $53 \pm 0.02^{\mathrm{a}}$ \\
\hline & South $(n=7)$ & $45.18 \pm 0.10^{\mathrm{a}}$ & $-0.56 \pm 0.04^{\mathrm{i}}$ & $31.87 \pm 0.15^{\mathrm{a}}$ & $7.91 \pm 0.09^{\mathrm{a}}$ & $-1.55 \pm 0.03^{\mathrm{i}}$ & $43 \pm 0.05^{\mathrm{d}}$ \\
\hline \multirow{3}{*}{ Sunflower } & North $(n=5)$ & $31.03 \pm 0.01^{\mathrm{e}}$ & $1.93 \pm 0.05^{\mathrm{f}}$ & $17.56 \pm 0.01^{\mathrm{d}}$ & $6.25 \pm 0.04^{\mathrm{d}}$ & $1.46 \pm 0.09^{\mathrm{b}}$ & $37 \pm 0.08^{\mathrm{e}}$ \\
\hline & Center $(n=8)$ & $38.10 \pm 0.02^{\mathrm{c}}$ & $1.37 \pm 0.01^{\mathrm{g}}$ & $24.71 \pm 0.03^{\mathrm{b}}$ & $6.79 \pm 0.13^{\mathrm{b}}$ & $1.02 \pm 0.04^{\mathrm{g}}$ & $41 \pm 0.02^{\mathrm{d}}$ \\
\hline & South $(n=5)$ & $28.24 \pm 0.15^{\mathrm{g}}$ & $3.53 \pm 0.03^{\mathrm{a}}$ & $11.65 \pm 0.03^{h}$ & $5.51 \pm 0.10^{\mathrm{h}}$ & $1.28 \pm 0.07^{\mathrm{f}}$ & $39 \pm 0.07^{\mathrm{e}}$ \\
\hline \multirow{3}{*}{ Linden } & North $(n=5)$ & $29.39 \pm 0.15^{\mathrm{f}}$ & $2.66 \pm 0.06^{\mathrm{d}}$ & $14.75 \pm 0.13^{\mathrm{f}}$ & $5.90 \pm 0.03^{e}$ & $1.39 \pm 0.12^{\mathrm{d}}$ & $22 \pm 0.09^{g}$ \\
\hline & Center $(\mathrm{n}=7)$ & $30.81 \pm 0.29^{\mathrm{e}}$ & $3.05 \pm 0.07^{c}$ & $16.15 \pm 0.11^{\mathrm{e}}$ & $6.20 \pm 0.01^{\mathrm{d}}$ & $1.38 \pm 0.19^{\mathrm{d}}$ & $38 \pm 0.06^{\mathrm{e}}$ \\
\hline & South $(\mathrm{n}=5)$ & $43.46 \pm 0.09^{\mathrm{b}}$ & $0.90 \pm 0.03^{\mathrm{h}}$ & $15.96 \pm 0.02^{\mathrm{e}}$ & $5.81 \pm 0.15^{\mathrm{f}}$ & $1.51 \pm 0.01^{\mathrm{a}}$ & $34 \pm 0.04^{\mathrm{c}}$ \\
\hline
\end{tabular}

also the result of linden honey from South area were close to zero (0.90). However, samples from central Moldova showed an average of 3.05, which indicates the presence of reddish pollen [35] [36].

The data of $b^{\star}$ axis, representing the positive values a shift toward yellow color, and the negative values a shift toward blue color. All samples had only positive values $b$. The most yellowish samples were polyfloral honey from south of Moldova (mean values 31.87) followed a sunflower honey from center of Moldova (mean values 24.71).

The Chroma or colorfulness of an area represents the amount of color and increase with the brightness having the clearest honey the higher values of Chroma. The lower values are shown for the dark honey and the highest values are shown for the light honey. The CIELab coordinates were useful for distinguishing monochromatic honeys by hue and color, and for better differentiating between honey varieties [37] [38].

A scale Pfund used in the honey industry to describe the color of honey. Color values presented in Pfund scale (water white, extra white, white, extra light amber, light amber, amber and dark amber) in order to classify honey colors. The colors of the studied samples varied from white to extra light amber, and only polyfloral honey samples from the central part of Moldova were light amber [39].

\section{Conclusions}

For consumers in the Republic of Moldova, it is characteristic to purchase food products, including bee honey from small local producers, who distribute the products directly from them, through agricultural markets and specialized fairs. Purchasing products in these ways is a national tradition. The preservation of this tradition is due to the consumers' conviction of the high quality of local products, and honey is an empirical product for the given geographical area.

At the same time, one of the major impacts of the Covid-19 pandemic is li- 
miting the population's access to food, including honey. The research showed that the assortment of honey and the producers' presence in the main supermarkets in the Republic of Moldova are very limited.

Experimental samples of honey were purchased directly from local beekeepers, who did not have the opportunity to market their products during the Covid-19 pandemic and they were not available in large supermarket chains. For this reason, during the pandemic consumers were limited in choosing a quality local product. The physico-chemical indicators of the studied honey samples fall within the values allowed in both local and international regulations.

\section{Acknowledgements}

The research was made possible by the project „Développement durable de l'apiculture: Enjeux économique, écologiques, de développement rural et de santé publique", supported by the Ministry of Education, Culture and Research of the Republic of Moldova and the Francophone University Agency (AUF-MECR 2021/4), carried out within the Department of Food and Nutrition of the Technical University of Moldova.

\section{Conflicts of Interest}

The authors declare no conflicts of interest regarding the publication of this paper.

\section{References}

[1] Morei, V. (2011) Beekeeping Practice Opportunity in the Context of Sustainable Development of Rural Areas. Scientific Papers Series-Management, Economic Engineering in Agriculture and Rural Development, 11, 155-160.

[2] Cosmina, M., Gallenti, G., Marangon, F. and Troiano, S. (2016) Reprint of "Attitudes towards Honey among Italian Consumers: A Choice Experiment Approach". Appetite, 106, 110-116. https://doi.org/10.1016/j.appet.2016.08.005

[3] Brščić, K., Šugar, T. and Poljuha, D. (2017) An Empirical Examination of Consumer Preferences for Honey in Croatia. Applied Economics, 49, 5877-5889. https://doi.org/10.1080/00036846.2017.1352079

[4] Berger, J. (2018) European Market Assessment for the Main Organic Export Products from Armenia, Moldova and Ukraine. United Nations Environment Programme.

[5] Eremia, N., Scripnic, E., Modvala, S. and Chiriac, A. (2017) Influence of Temperature on Nectar Collection and Storage in the Hive during Honey Harvest. University of Agricultural Sciences and Veterinary Medicine Iasi, Iasi.

[6] https://www.mold-street.com/?go=news\&n=11189

[7] How Much Honey Did Moldova Produce in 2019 and in Which Countries Does It Export It. https://ecopresa.md/infografic-cata-miere-a-produs-moldova-in-2019-si-in-ce-tario-exporta/

[8] Programul Național de Dezvoltare a Apiculturii Republica Moldova 2020-2026.

[9] Pocol, C.B. (2011) Sustainable Policies for the Development of Beekeeping in Romania. Problems of World Agriculture, 11, 107-114.

[10] Bommuraj, V., Chen, Y., Klein, H., Sperling, R., Barel, S. and Shimshoni, J.A. (2019) 
Pesticide and Trace Element Residues in Honey and Beeswax Combs from Israel in Association with Human Risk Assessment and Honey Adulteration. Food Chemistry, 299, Article ID: 125123. https://doi.org/10.1016/j.foodchem.2019.125123

[11] Chirsanova, A., Capcanari, T. and Boistean, A. (2021) Bee Honey: History, Characteristics, Properties, Benefits and Adulteration in the Beekeeping Sector. Journal of Social Sciences, 4, 98-114.

[12] Authenticité du Miel: Une méthode globale et sensible. https://www.eurofins.fr/media/1030201/eurofins-flyer-authenticité-du-miel.pdf

[13] Potop, V. and Soukup, J. (2009) Spatiotemporal Characteristics of Dryness and Drought in the Republic of Moldova. Theoretical and Applied Climatology, 96, 305-318. https://doi.org/10.1007/s00704-008-0041-5

[14] Chirsanova, A., Capcanari, T., Boistean, A. and Siminiuc, R. (2021) Physico-Chemical Profile of Four Types of Honey from the South of the Republic of Moldova. Food and Nutrition Sciences, 12, 874-888. https://doi.org/10.4236/fns.2021.129065

[15] Eremia, N., Naraevscaia, I. and Chiriac, A. (2016) Indicii fizico-chimici şi limitele elementelor toxice în mierea de albine. Ştiința Agricolă, 1, 109-116.

[16] Eremia, N., Dabija, T. and Dodon, I. (2010) Micro-and Mactoelements Content Soil, Plants Necttaro-Pollenifer Leaves, Pollen and Bees Body. Scientific Papers: Animal Science and Biotechnologies, 43, 180-182.

[17] Chirsanova, A., Capcanari, T. and Boistean, A. (2021) Palynological, Physico-Chemical and Biologically Active Substances Profile in Some Types of Honey in the Republic of Moldova. Journal of Engineering Science, 28, 175-186. https://doi.org/10.52326/jes.utm.2021.28(3).14

[18] Codex Alimentarius Commission (2019) Standard for Honey CXS 12-1981.

[19] Chuttong, B., Phongphisutthinant, R., Sringarm, K., Burgett, M. and Barth, O.M. (2018) Nutritional Composition of Pot-Pollen from Four Species of Stingless Bees (Meliponini) in Southeast Asia. In: Vit, P., Pedro, S. and Roubik, D., Eds., Pot-Pollen in Stingless Bee Melittology, Springer, Cham, 313-324.

https://doi.org/10.1007/978-3-319-61839-5 22

[20] Karabagias, I.K. and Karabournioti, S. (2018) Discrimination of Clover and Citrus Honeys from Egypt According to Floral Type Using Easily Assessable Physicochemical Parameters and Discriminant Analysis: An External Validation of the Chemometric Approach. Foods, 7, Article ID: 70. https://doi.org/10.3390/foods7050070

[21] Scholz, M.B.S., Quinhone Júnior, A., Delamuta, B.H. et al. (2020) Indication of the Geographical Origin of Honey Using Its Physicochemical Characteristics and Multivariate Analysis. Journal of Food Science and Technology, 57, 1896-1903. https://doi.org/10.1007/s13197-019-04225-3

[22] Popescu, A. and Guresoaie, I. (2019) Consumer's Behaviour towards Honey Purchase-A Case Study in Romania. Scientific Papers Series Management. Economic Engineering in Agriculture and Rural Development, 19, 451-469.

[23] Khamid, K. and Danchuk, O. (2021) Evaluation of Quality Indicators of Honey of Different Origin. Agrarian Bulletin of the Black Sea Littoral, 98, 111-114.

[24] Tuberoso, C.I.G., Bifulco, E., Caboni, P., Cottiglia, F., Cabras, P. and Floris, I. (2010) Floral Markers of Strawberry Tree (Arbutus unedo L.) Honey. Journal of Agricultural and Food Chemistry, 58, 384-389. https://doi.org/10.1021/jf9024147

[25] Mădaş, M.N., Mărghitaş, L.A. and Dezmirean, D.S. (2019) Labeling Regulations and Quality Control of Honey Origin: A Review. Food Reviews International, 36, 215 - 
240. https://doi.org/10.1080/87559129.2019.1636063

[26] Erkan, A.P. (2021) Pollen Analysis of Chestnut Honey in Some Provinces of the Black Sea Region, Turkey. Mellifera, 20, 18-31

[27] Modvala, S., Eremia, N. and Scripnic, E. (2014) The Technology of Pastoral Beekeeping. Scientific Papers-Animal Science Series, 66, 29-34.

[28] Government Decision No. 768 of 21-10-2020 on the Approval of the National Program for the Development of Beekeeping in the Republic of Moldova for the Years 2021-2025. https://www.legis.md/cautare/getResults?doc id=123890\&lang=ro

[29] Pauliuc, D., Dranca, F. and Oroian, M. (2020) Antioxidant Activity, Total Phenolic Content, Individual Phenolics and Physicochemical Parameters Suitability for Romanian Honey Authentication. Foods, 9, Article ID: 306. https://doi.org/10.3390/foods9030306

[30] Government Decision No. 1143 din 21.11.18, MO13-21/18.01.19 on the Approval of the Technical Regulation "Natural Honey" in the Republic of Moldova.

[31] Arzoumanidis, I., Raggi, A. and Petti, L. (2019) Life Cycle Assessment of Honey: Considering the Pollination Service. Administrative Sciences, 9, Article ID: 27. https://doi.org/10.3390/admsci9010027

[32] Bogdanov, S. (2010) Nutritional and Functional Properties of Honey. Vopr Pitan, 79, 4-13.

[33] Tsagkaris, A.S., et al. (2021) Honey Authenticity: Analytical Techniques, State of the Art and Challenges. RSC Advances, 11, 11273-11294. https://doi.org/10.1039/D1RA00069A

[34] Małgorzata, S., et al. (2021) Characterizing the Volatile and Sensory Profiles, and Sugar Content of Beeswax, Beebread, Bee Pollen, and Honey. Molecules, 26, Article ID: 3410 . https://doi.org/10.3390/molecules26113410

[35] Małgorzata, S., Ostaszyk, A. and Zieliński, H. (2021) The Relationship between the Browning Index, Total Phenolics, Color, and Antioxidant Activity of Polish-Originated Honey Samples. Foods, 10, Article ID: 967.

https://doi.org/10.3390/foods10050967

[36] Boiştean, A., Chirsanova, A., Capcanari, T. and Siminiuc, R. (2021) Evaluation of the Color as a Characterization Parameter of Honey from Tunisia, Romania and Moldova. Biotehnologii Modern-Soluții Pentru Provocările Lumii Contemporane 2021, 43. https://doi.org/10.52757/imb21.009

[37] Aida, A., et al. (2021) Quality Assessment of Raw Honey Issued from Eastern Romania. Agriculture, 11, Article ID: 247. https://doi.org/10.3390/agriculture11030247

[38] Asma, G., et al. (2021) Sensorial, Melissopalynological and Physicochemical Characteristics of Honey from Babors Kabylia's Region (Algeria). Foods, 10, Article ID: 225. https://doi.org/10.3390/foods10020225

[39] Kanbur, E.D., et al. (2021) A Comparison of the Physicochemical Properties of Chestnut and Highland Honey: The Case of Senoz Valley in the Rize Province of Turkey. Food Chemistry, 345, Article ID: 128864. https://doi.org/10.1016/j.foodchem.2020.128864 